\title{
THE INTERNATIONALISATION OF HIGHER EDUCATION IN THE REGIONS: CASE OF LATVIA
}

Inga Jekabsone ${ }^{1}$, Dr.sc.admin., assist.prof.

${ }^{1}$ RISEBA University of Applied Sciences

\begin{abstract}
Internationalisation is set as a horizontal priority of higher education in the context of the quality assurance by the government of Latvia. However, higher education institutions (hereinafter - HEI) in Latvia find it challenging to attract talented international students and academic staff, especially in the regions, thereby the internationalisation rates in HEI differ. The internationalisation is a complex concept - it is understood not only by the attraction of international students and academic staff, but also by internationalisation of local students and staff as well as by creation of inclusive environment for both - international and local students and staff. Taking into account before mentioned, the aim of the research is to analyse the dimensions of the internationalisation of regional HEI in Latvia.

During the research, six regional HEI in Latvia were analysed in the context of diverse aspects of internationalisation. Recommendations to regional HEI were developed based on the analysis of case studies.

The analysis showed that the internationalisation in the regional HEI in Latvia are mainly focused on attraction of international students and on student and academic staff mobility. At the same time, some of the regional HEI set the internalisation as a priority while others focus more on local students and regional needs. However, most of regional HEI in Latvia lag behind the average EU un national internationalisation rates.
\end{abstract}

Key words: higher education, internationalisation, regions, Latvia.

JEL code: I23, I25, R11

\section{Introduction}

In general, internationalisation of higher education promotes higher quality of the education. One of the mostly used definitions of internationalisation is provided by Knight (2008) who defines internationalisation as 'the process of integrating an international, intercultural or global dimension into the purpose, functions or delivery of post-secondary education' and is recognised as a key component of higher education institutions. The European Parliament (2015) offers revised definition of internationalisation as 'the intentional process of integrating an international, intercultural or global dimension into the purpose, functions and delivery of post-secondary education, in order to enhance the quality of education and research for all students and staff, and to make a meaningful contribution to society'. This definition reflects the increased awareness that internationalisation has to become more inclusive and less elitist.

Pertaining to the features of the internationalisation of higher education, this process has become a global phenomenon which embraces all aspects of service provision in this key education sector (Bernnell, 2020; Altbach and Knight, 2007; Ennew and Greenaway, 2012; Kapur and Crowley, 2008). There are different focuses of internationalisation, e.g. in the Europe, most of universities are focusing on the delivery of the academic study programmes in English, while Scandinavian universities concentrate on mobility, in turn, in the UK internationalisation has focus on student recruitment (Clarke et al., 2018).

At political level the importance of internationalisation of higher education is highly stipulated. The EU Member States have committed themselves to promoting the learning mobility of young people following the Communication on an agenda for the modernisation of Europe's higher education system (European Commission, 2011). The Council conclusions on a benchmark for learning mobility specified that by 2020 'an EU average of at least $20 \%$ of higher education graduates should have

${ }^{1}$ jekabsone_inga@inbox.Iv; +37127116147 
had a period of higher education-related study or training abroad' (The Council of the European Union, 2011).

Many case studies (Andalusia, Spain; Wroclaw, Poland) prove that at regional level higher education institutions are key stakeholders of the economy and society by developing study programmes that satisfy regional needs and develop human capital, ensuring research specialisation and institutional innovation that corresponds to the regional development (OECD, 2010; OECD, 2012). However, HEI located in the regions tend to struggle when it comes to attracting talented students and academic personnel as well as competitive funding. In many cases, regional higher education institutions lack in-house research capacity that limits their impact on regional development of the area (Pinheiro et al., 2018).

One of analysed examples of HEI internationalisation in the regions is Poland's case study. In Poland, some regions have taken the initiative to promote their local area to foreign students. Local governments and local HEIs have co-operated to attract foreign students looking for long-term and short-term study opportunities within European programmes and those who are interested in learning more about the city and region where they will study. For example, Wroclaw local government has an initiative administered jointly with participating universities (Study in Wroclaw, n.d.) and directed at Eastern European students (mostly Ukrainians and Belarusians); Lublin City Council (n.d.) and Poznan City Council (n.d.) have region-wide promotion projects. Poznan is thinking comprehensively about internationalisation and does have a strategy of internationalisation, which was initiated by the Adam Mickiewicz University of Poznan (the only HEI in Poland which has a separate institutional internationalisation strategy). Moreover, one regional initiative has been operating without the support of local government or authorities, namely the Silesian University Network (n.d.). The network provides information about nine public higher education institutions from Silesia and their offer to the Erasmus exchange student (European Parliament, 2015).

The Ministry of Education and Science of Latvia has set the internationalisation of higher education and science as a horizontal priority in the planning period 2014-2020 (Ministry of Education and Science, 2014). Recent official results on the number of foreign students state that 8310 international students are studying in Latvia (or 10\% of all students) (Ministry of Education and Science, 2019). According to the ongoing debate on change of internal governance model of higher education institutions, the Ministry of Education and Science has proposed criteria to universities (universitate) and universities of applied sciences (augstskolas) regarding attraction of international students and international academic personnel, e.g. until 2027, every university ensures $15 \%$ share of international students (university of applied sciences - 10\%) and $10 \%$ share of international academic staff (the same for universities of applied sciences). In addition, the Ministry also has proposed stricter rules regarding opening of branches of HEI abroad (Ministry of Education and Science, 2020).

In case of regional HEI in Latvia, the internationalisation is also on their agenda taking into consideration the need for increasing the academic as well as scientific capacity. Regional HEIs Latvia University of Life Sciences and Technologies (hereinafter - LLU), Daugavpils University (hereinafter - DU), Vidzeme University of Applied Sciences (hereinafter - ViA), Ventspils University of Applied Sciences (hereinafter - VeA), Rezekne Academy of Technologies (hereinafter - RTA), Liepaja University (hereinafter - LiepU) - show stable internationalisation rates or rather positive dynamics. However, the approaches of regional institutions are different and most of the regional 
higher education institutions would have challenges to meet new requirements of the Ministry of Education and Science regarding the share of international students and international academic staff.

Research question: On what dimensions of internationalisation of higher education do regional HEI in Latvia focus?

Taking into account the before mentioned facts, the aim of the research is to analyse the dimensions of the internationalisation of HEI in the regions of Latvia.

The tasks are formulated as follows:

1) to review scientific background and empirical research on different dimensions of internationalisation of higher education;

2) to assess the internationalisation approaches of the regional HEI in Latvia;

3) to provide recommendations for regional HEI in Latvia how to enhance internationalisation.

In order to achieve the aim, the following research methods are used: scientific literature studies, statistical data analysis, case study method, expert interviews.

Delimitations of the research subjects: only state funded higher education institutions would be analysed: LLU, DU, ViA, VeA, RTA, and LiepU. The impact of the HEI on regional development will not be analysed.

Main information sources: scientific literature, published studies, political planning documents and normative legal acts, as well as official statistical databases.

Novelty and topicality of the research includes the analysis of the regional HEI in Latvia in the context of ongoing reforms on changing internal governance (dimension "regional development" and "internationalisation").

\section{Research results and discussion}

In this section, the analysis of the regional HEI in Latvia is provided, taking into consideration different dimensions of internationalisation of higher education.

\section{General analysis of regional HEI in Latvia}

According to the recent available data, in Latvia there are 16 state HEI and 13 private HEI. Total number of students in academic year 2018/2019 is 80355 students. $10 \%$ of them are international students (10 503 students), while 6\% all total academic staff is from abroad (Ministry of Education and Science, 2020). The number of foreign students tends to increase each year (Fig.1). Thereby, the objective stated at the Guidelines for the Development of Education 2014-2020 is fulfilled - $10 \%$ of all students are foreign students (Latvijas Vestnesis, 2014). From the perspective of Latvian HEI, the growing reliance on international students as a major source of income is linked with significant declines in government funding, as well as the demographic calculus in Latvia (Chankseliani and Wells, 2019). However, in the next decade these statistics may deteriorate as it is predicted that outbound student mobility will likely decline globally because of the dampening effect of the improved domestic provision on outbound student flows (British Council, 2018). 


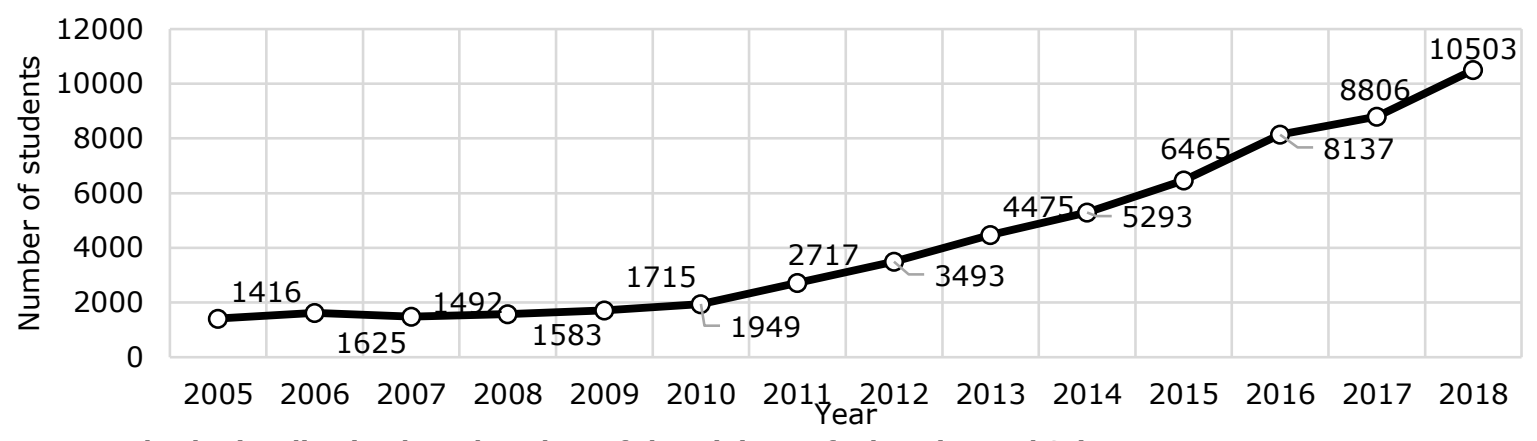

Source: author's visualisation based on data of the Ministry of Education and Science

Fig. 1. Number of foreign students in Latvia 2005-2018

There are 6 state funded regional HEI in Latvia: LLU, DU, ViA, VeA, RTA, and LiepU. Main statistics of these HEI is illustrated in Table 1.

Table 1

Main statistics of regional HEI in Latvia in 2018/2019 academic year

\begin{tabular}{|l|c|c|c|c|c|}
\hline HEI & $\begin{array}{c}\text { Number } \\
\text { of } \\
\text { students }\end{array}$ & $\begin{array}{c}\text { Number } \\
\text { of } \\
\text { academic } \\
\text { staff }\end{array}$ & $\begin{array}{c}\text { Number of } \\
\text { international } \\
\text { students (\% of } \\
\text { total number of } \\
\text { students) }\end{array}$ & $\begin{array}{c}\text { Number of } \\
\text { international academic } \\
\text { staff (\% of total } \\
\text { number of academic } \\
\text { staff) }\end{array}$ & $\begin{array}{c}\text { Number of Latvian } \\
\text { mobility students } \\
\text { (\% of total number } \\
\text { of students) }\end{array}$ \\
\hline LLU & 3880 & 438 & $77(2 \%)$ & $15(3 \%)$ & $110(3 \%)$ \\
\hline DU & 2514 & 213 & $43(2 \%)$ & $2(1 \%)$ & $91(4 \%)$ \\
\hline ViA & 742 & 115 & $7(1 \%)$ & $19(17 \%)$ & $26(4 \%)$ \\
\hline VeA & 794 & 121 & $39(5 \%)$ & $3(2 \%)$ & $34(4 \%)$ \\
\hline RTA & 1753 & 145 & $169(10 \%)$ & $12(8 \%)$ & $47(3 \%)$ \\
\hline LiepU & 1373 & 212 & $97(7 \%)$ & $13(6 \%)$ & $33(2 \%)$ \\
\hline
\end{tabular}

Source: The Ministry of Education and Science, 2019

LLU is the 4th largest HEI in Latvia regarding the number of students. According to the proposal of the Ministry of Education and Science (Ministry of Education and Science, 2020), LLU is the only regional HEI that could meet the criteria regarding of the number of students to be called the university (requirement: at least 4000 students). By this scenario, DU and LiepU will lose the status of the university and would be classified as the universities of applied sciences. In turn, ViA and VeA do not meet the criteria to be called the universities of applied sciences as the number of students in these HEI is below 1000 students. Pertaining to the number of international students, in the regional HEI it varies from $1 \%$ to $10 \%$. In $\mathrm{ViA}$, the share of international students is only $1 \%$, in turn, in DU and LLU it is only $2 \%$. Only in RTA the share of international students corresponds to the national tendencies. As concerns the international academic staff, in ViA and RTA the share of international academic staff exceeds the average national level of international academic staff. Regarding to DU and VeA, there are only few cases of international academic staff employment. The share of mobility students is slightly higher in the regional HEI than the average in Latvia, where $2 \%$ of all Latvian students use mobility possibilities.

\section{Methodology of analysis of internationalisation of higher education}

Considering the versatile nature of internationalisation of higher education as well as conclusions of the scientific literature review, the analysis of regional HEI in Latvia is provided focusing on these dimensions: administrative perspective, teaching and learning perspective, environmental perspective (Fig. 2). 

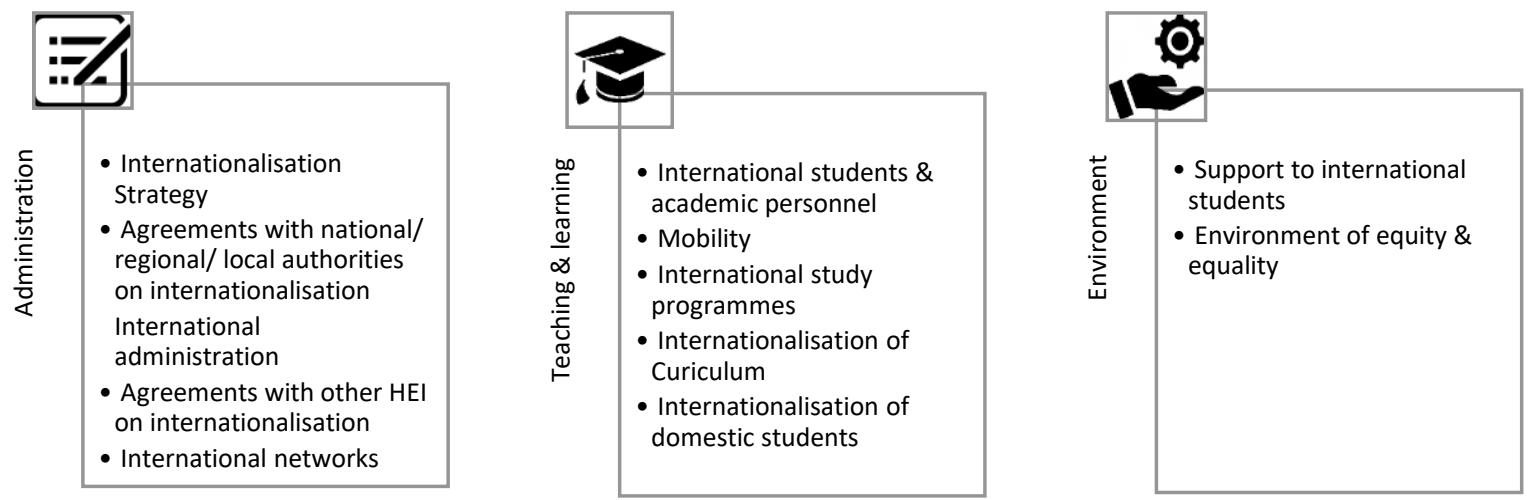

Source: author's visualisation based on Clarke et al., 2018; Smaliakou, 2019; Bernnell, 2020

Fig. 2. Dimensions of higher education internationalisation

Taking into account these criteria, the case study analysis is provided for regional HEI in Latvia. For this purpose, the publicly available information (HEI website, reports, interviews with employees, statistical data, scientific publications etc.) was studied as well as the interviews with high level representatives of the HEI were organised.

\section{Analysis of regional HEI in the context of internationalisation of higher education}

All six regional HEI in Latvia were analysed in the context of internationalisation. The results of the study are displayed in Table 2.

Table 2

\section{Analysis of internationalisation aspects in the regional HEI in Latvia}

\begin{tabular}{|c|c|c|c|}
\hline \multirow{2}{*}{ HEI } & \multicolumn{3}{|c|}{ Internationalisation dimensions } \\
\hline & Administration & Teaching and learning & Environment \\
\hline LLU & $\begin{array}{l}\text { Internationalisation Strategy: In the } \\
\text { Development Strategy, one of medium- } \\
\text { term objectives for higher education - } \\
\text { to ensure internationalisation of studies } \\
\text { un lifelong learning. In addition, } \\
\text { internationalisation plans have been } \\
\text { prepared. } \\
\text { Agreements on internationalisation: } \\
\text { LLU is a member of Latvian Higher } \\
\text { Education Export Association; signed } \\
\text { agreement with Ministry of Education } \\
\text { and Science on good practice in } \\
\text { attracting foreign students. } \\
\text { International administration: LLU } \\
\text { has established International Advisory } \\
\text { Board. } \\
\text { Agreements with other HEI on } \\
\text { internationalisation: a large number } \\
\text { of agreements (161) within Erasmus+; } \\
\text { bilateral agreements with } 24 \text { foreign } \\
\text { HEI and with } 37 \text { international } \\
\text { associations. } \\
\text { International networks: wide } \\
\text { network of international partners (e.g. } \\
\text { The International Association of } \\
\text { Universities, The European Association } \\
\text { of Universities). }\end{array}$ & $\begin{array}{l}\text { International students \& academic } \\
\text { personnel: The share of international } \\
\text { students and academic staff is relatively } \\
\text { small (respectively } 2 \% \text { and } 3 \% \text { ). In the } \\
\text { Development Strategy it is stipulated that } \\
\text { LLU shall provide an offer that attracts } \\
\text { international students. } \\
\text { Mobility: both inbound and outbound } \\
\text { student and academic staff mobility tends } \\
\text { to increase, however the numbers are } \\
\text { relatively small. More focus is on academic } \\
\text { staff mobility (inbound mobility } 103 \text {; } \\
\text { outbound mobility } 73 \text { ). } \\
\text { International study programmes: } 5 \\
\text { bachelor programmes, } 8 \text { master } \\
\text { programmes and } 13 \text { doctoral programmes } \\
\text { in ENG. } \\
\text { Internationalisation of Curriculum: } \\
\text { ESF project "Improvement of Management } \\
\text { of LLU" that includes adjustment of } \\
\text { curriculum to the internationalisation } \\
\text { trends. } \\
\text { Internationalisation of domestic } \\
\text { students: Relatively small share of } \\
\text { students uses mobility possibilities ( } 3 \% \text { ). }\end{array}$ & $\begin{array}{l}\text { Support to } \\
\text { international students: } \\
52 \text { international } \\
\text { recruitment agents. } \\
\text { The webpage with } \\
\text { relevant information for } \\
\text { international students was } \\
\text { developed. } \\
\text { The Centre for } \\
\text { International Cooperation } \\
\text { and Language Centre was } \\
\text { established. } \\
\text { Environment of equity } \\
\text { and equality: not } \\
\text { highlighted. }\end{array}$ \\
\hline
\end{tabular}




\begin{tabular}{|c|c|c|c|}
\hline \multirow{2}{*}{ HEI } & \multicolumn{3}{|c|}{ Internationalisation dimensions } \\
\hline & Administration & Teaching and learning & Environment \\
\hline DU & $\begin{array}{l}\text { Internationalisation Strategy: In the } \\
\text { Development Strategy, the } \\
\text { internationalisation of HEI is not } \\
\text { highlighted as the priority. } \\
\text { Agreements on internationalisation: } \\
\text { signed agreement with the Ministry of } \\
\text { Education and Science on good practice } \\
\text { in attracting foreign students. } \\
\text { International administration: non. } \\
\text { Agreements with other HEI on } \\
\text { internationalisation: a large number } \\
\text { of agreements (129) within Erasmus+, } \\
\text { bilateral agreements with } 48 \text { foreign } \\
\text { HEI and with } 3 \text { international } \\
\text { associations. } \\
\text { International networks: wide } \\
\text { network of international partners (e.g. } \\
\text { The European Union Universities of } \\
\text { Small States, The European Association } \\
\text { of Universities). }\end{array}$ & $\begin{array}{l}\text { International students and academic } \\
\text { personnel: The share of international } \\
\text { students and academic staff is relatively } \\
\text { small (respectively } 1 \% \text { and } 2 \% \text { ). } \\
\text { Mobility: outbound student mobility } 91 \\
\text { students (slight increase over the last } \\
\text { years). } \\
\text { International study programmes: } 5 \\
\text { bachelor programmes, } 7 \text { master } \\
\text { programmes. and } 11 \text { doctoral programmes } \\
\text { in ENG. } \\
\text { Internationalisation of Curriculum: } \\
\text { ESF project "Reducing fragmentation of } \\
\text { study programmes and strengthening } \\
\text { resource sharing at Daugavpils University" } \\
\text { that includes adjustment of curriculum to } \\
\text { the internationalisation trends. } \\
\text { Internationalisation of domestic } \\
\text { students: Relatively small share of } \\
\text { students that use mobility possibilities } \\
\text { (4\%). }\end{array}$ & $\begin{array}{l}\text { Support to } \\
\text { international students: } \\
\text { Department of } \\
\text { International and public } \\
\text { relation provides the } \\
\text { support for international } \\
\text { students. The webpage } \\
\text { with relevant information } \\
\text { for international students } \\
\text { was developed. } \\
\text { Environment of equity } \\
\text { \& equality: In the } \\
\text { Development Strategy it is } \\
\text { indicated, that flexibility of } \\
\text { study programmes allows } \\
\text { to combine studies with } \\
\text { work, child care, health } \\
\text { care and other aspects of } \\
\text { personal life. }\end{array}$ \\
\hline ViA & $\begin{array}{l}\text { Internationalisation Strategy: In the } \\
\text { Development Strategy, it is mentioned } \\
\text { that an important precondition for the } \\
\text { development of ViA has been } \\
\text { international cooperation and the study } \\
\text { process internationalisation. However, } \\
\text { the internationalisation of HEI is not } \\
\text { highlighted as the priority. Horizontal } \\
\text { direction - strengthening national and } \\
\text { international collaboration networks. } \\
\text { Agreements on internationalisation: } \\
\text { signed agreement with the Ministry of } \\
\text { Education and Science on good practice } \\
\text { in attracting foreign students. } \\
\text { International administration: non } \\
\text { Agreements with other HEI on } \\
\text { internationalisation: a large number } \\
\text { of agreements (120) within Erasmus+. } \\
\text { International networks: non. }\end{array}$ & $\begin{array}{l}\text { International students and academic } \\
\text { personnel: The share of international } \\
\text { students is relatively small (respectively } \\
1 \%) \text {. However, the share of international } \\
\text { academic staff exceeds the average level } \\
(17 \%) \text {. } \\
\text { Mobility: outbound student mobility - } 26 \\
\text { students (slight increase over the last } \\
\text { years). } \\
\text { International study programmes: } 1 \\
\text { bachelor programme, } 5 \text { master } \\
\text { programmes and } 1 \text { doctoral programme in } \\
\text { ENG. } \\
\text { Internationalisation of Curriculum: } 1 \\
\text { joint master programme; NORDPLUS } \\
\text { project "Integrating responsible } \\
\text { consumption in higher education } \\
\text { programmes". } \\
\text { Internationalisation of domestic } \\
\text { students: Relatively small share of } \\
\text { students uses mobility possibilities (4 \%). }\end{array}$ & $\begin{array}{l}\text { Support to } \\
\text { international students: } \\
\text { the webpage with relevant } \\
\text { information for } \\
\text { international students was } \\
\text { developed. One position of } \\
\text { international studies } \\
\text { specialist. } \\
\text { Environment of equity } \\
\text { and equality: Open } \\
\text { university and remote } \\
\text { work place opportunities } \\
\text { for stakeholders. }\end{array}$ \\
\hline VeA & $\begin{array}{l}\text { Internationalisation Strategy: In } \\
\text { the Development Strategy, one of the } \\
\text { objectives indicates the need to } \\
\text { strengthen the national and } \\
\text { international collaboration networks. } \\
\text { However, the internationalisation of HEI } \\
\text { is not highlighted as the priority. } \\
\text { Agreements on internationalisation: } \\
\text { signed agreement with the Ministry of } \\
\text { Education and Science on good practice } \\
\text { in attracting foreign students. } \\
\text { International administration: } \\
\text { International Advisory Council. } \\
\text { Agreements with other HEI on } \\
\text { internationalisation: a large number } \\
\text { of agreements (96) within Erasmus+, } \\
\text { bilateral agreements with } 28 \text { foreign } \\
\text { HEI and with } 3 \text { international } \\
\text { associations. } \\
\text { International networks: non. }\end{array}$ & $\begin{array}{l}\text { International students and academic } \\
\text { personnel: The share of international } \\
\text { students and academic staff is relatively } \\
\text { small (respectively } 5 \% \text { and } 2 \% \text { ). } \\
\text { Mobility: outbound student mobility - } 32 \\
\text { students (slight increase over the last } \\
\text { years). } \\
\text { International study programmes: } 5 \\
\text { bachelor programme and } 1 \text { master } \\
\text { programme in ENG. } \\
\text { Internationalisation of Curriculum: } \\
\text { ESF project "Improvement of VeA study } \\
\text { programme content quality, resource } \\
\text { efficiency and better management" that } \\
\text { includes adjustment of curriculum to the } \\
\text { internationalisation trends; } 1 \text { joint master } \\
\text { programme. } \\
\text { Internationalisation of domestic } \\
\text { students: Relatively small share of } \\
\text { students uses mobility possibilities ( } 4 \% \text { ). }\end{array}$ & $\begin{array}{l}\text { Support to } \\
\text { international students: } \\
\text { the webpage with relevant } \\
\text { information for } \\
\text { international students was } \\
\text { developed. Two positions } \\
\text { for a foreign affairs } \\
\text { specialists, one position of } \\
\text { an expert in attracting } \\
\text { foreign students. } \\
\text { Environment of equity } \\
\text { and equality: not } \\
\text { highlighted. }\end{array}$ \\
\hline RTA & $\begin{array}{l}\text { Internationalisation Strategy: As } \\
\text { stated in the Development Strategy, } \\
\text { one of the RTA's priorities is the } \\
\text { internationalisation of the study and } \\
\text { research process. The } \\
\text { internationalisation of HE is understood } \\
\text { as exchange of students and academic } \\
\text { staff, development of study } \\
\text { programmes in ENG and joint } \\
\text { programmes, attraction of foreign } \\
\text { students. } \\
\text { Agreements on internationalisation: } \\
\text { non. } \\
\text { International administration: non } \\
\text { Agreements with other HEI on } \\
\text { internationalisation: a large number } \\
\text { of agreements (101) within Erasmus+. } \\
\text { International networks: non. }\end{array}$ & $\begin{array}{l}\text { International students and academic } \\
\text { personnel: The share of international } \\
\text { students and academic staff is on average } \\
\text { national level (respectively } 10 \% \text { and } 8 \% \text { ). } \\
\text { Mobility: outbound mobility - } 47 \text { students } \\
\text { (slight increase over the last years). } \\
\text { International study programmes: } 5 \\
\text { bachelor programmes, } 7 \text { master } \\
\text { programmes and } 2 \text { doctoral programmes } \\
\text { in ENG. } \\
\text { Internationalisation of Curriculum: } \\
\text { ESF projects on reducing fragmentation of } \\
\text { study programmes and strengthening } \\
\text { resource sharing. } \\
\text { Internationalisation of domestic } \\
\text { students: Relatively small share of } \\
\text { students uses mobility possibilities (3\%). }\end{array}$ & $\begin{array}{l}\text { Support to } \\
\text { international students: } \\
\text { the webpage with } \\
\text { relevant information for } \\
\text { international students was } \\
\text { created. Established } \\
\text { position of study process } \\
\text { specialist for working with } \\
\text { foreign students. } \\
\text { Environment of equity } \\
\text { and equality: not } \\
\text { highlighted. }\end{array}$ \\
\hline
\end{tabular}




\begin{tabular}{|c|c|c|c|}
\hline \multirow{2}{*}{ HEI } & \multicolumn{3}{|c|}{ Internationalisation dimensions } \\
\hline & Administration & Teaching and learning & Environment \\
\hline LiepU & $\begin{array}{l}\text { Internationalisation Strategy: The } \\
\text { internationalisation of HEI is not } \\
\text { highlighted as the priority. } \\
\text { Agreements on internationalisation: } \\
\text { signed agreement with the Ministry of } \\
\text { Education and Science on good practice } \\
\text { in attracting foreign students. } \\
\text { International administration: non. } \\
\text { Agreements with other HEI on } \\
\text { internationalisation: a large number } \\
\text { of agreements (112) within Erasmus+. } \\
\text { International networks: non. }\end{array}$ & $\begin{array}{l}\text { International students and academic } \\
\text { personnel: The share of international } \\
\text { students and academic staff is slightly } \\
\text { below the average national level } \\
\text { (respectively } 7 \% \text { and } 6 \% \text { ). } \\
\text { Mobility: outbound student mobility - } 33 \\
\text { students (slight increase over the last } \\
\text { years). } \\
\text { International study programmes: } 3 \\
\text { bachelor programmes, } 3 \text { master } \\
\text { programmes and } 2 \text { doctoral programmes } \\
\text { in ENG. } \\
\text { Internationalisation of Curriculum: } \\
\text { ESF projects on reducing fragmentation of } \\
\text { study programs and strengthening } \\
\text { resource sharing. } \\
\text { Internationalisation of domestic } \\
\text { students: Relatively small share of } \\
\text { students uses mobility possibilities ( } 2 \% \text { ). }\end{array}$ & $\begin{array}{l}\text { Support to } \\
\text { international students: } \\
\text { the webpage with relevant } \\
\text { information for } \\
\text { international students was } \\
\text { developed. Foreign } \\
\text { communications } \\
\text { department ( } 4 \text { employees) } \\
\text { was established } \\
\text { Environment of equity } \\
\text { and equality: not } \\
\text { highlighted. }\end{array}$ \\
\hline
\end{tabular}

Source: websites of the HEI and interviews with administrative personnel

Referring to the administrative aspects of the internationalisation of the higher education, most of the HEI have signed the agreement with the Ministry of Education and Science of Latvia on good practice in attracting foreign students (except RTA). The Ministry had come up with this initiative in order to focus its marketing and administrative resources to promote only those HEI who attract foreign students according to the good practice. Some of the HEI (ViA and LLU) have International Advisory Board that brings additional international aspect to the management of the HEI. However, none of the HEI has foreign representatives in the government. All HEI have a large number of agreements with other HEI within Erasmus+, so there are wide opportunities for students and academic staff for mobility. At the same time, the number of students going on mobility could be higher. Larger HEI like LLU and DU are members of international organisations and networks, other HEI develop collaboration based on bilateral agreements with other HEI. In the Development Strategies of the HEI, mostly the international cooperation is set as a horizontal priority. Internationalisation of higher education directly is indicated as a priority in the case of LLU and RTA. No HEI has developed separate strategy for internationalisation. Also, at national level such strategy is not developed yet.

As concerns teaching and learning dimension, in this planning period all HEI are using the ESF funds for improvement of the content quality of the study programmes. It refers to the study programmes in English as well. In some cases, the internationalisation aspects are taken into account. All HEI offer the wide spectrum of study programmes in English, so foreign students can choose to study in the regions. The data show that in the most cases the share of international students and international staff is below the average national level. Only in RTA the share of international students and academic staff corresponds to the average national level. All HEI uses opportunities of Erasmus+, both students and academic staff; however, the share of mobility of students and academic staff is still not sufficient.

Pertaining to the environmental dimension, all regional HEI offer information about the study possibilities in English. There are special positions for employees who work with international students. In case of smaller HEI, the support function is executed by the Erasmus+ coordinators or employees of Student Department. Concerning the implementation of concept of environment of equity and equality, regional HEIs do not highlight this concept - taking into account that accessibility and availability of the higher education in Latvia in general remainsat good positions in the EU, especially regarding the gender balance. Environmental accessibility is regulated by the law. 
To sum up, the regional HEI in Latvia mostly associate the concept of internationalisation of the higher education with attraction of international students and with student and academic staff mobility. Other aspects of internationalisation such as internationalisation of curricula, internationalisation of local students or internationalisation of the governance of the HEI are not highlighted. This could be explained by the negative demographic tendencies and the need of the HEI for additional financial resources.

\section{Conclusions, proposals, recommendations}

1) The internationalisation of higher education is topical challenge for all HEI as it enhances both the quality of higher education and financial well-being of HEI. Taking into consideration the various aspects of the internationalisation concept, the most important dimensions of this concept are following: administrative, teaching and learning, and environmental.

2) In case of Latvia, the internationalisation of higher education is stated as a horizontal priority HEI have been actively working on attraction of international students. Regional HEI focus on attraction of international students as a major source of income due to significant declines in government funding, as well as the demographic calculus in Latvia.

3) In case of regional HEI in Latvia, mostly they are focusing on attraction of international students via widening the offer for study programmes in English. Also, regional HEI use Erasmus+ possibilities for student and staff mobility. As concerns other dimensions of internationalisation of higher education, regional HEI do not focus on creation of environment of equity and equality that supports inclusion of international students and staff to the daily life of HEI. Also, the internationalisation of the governance of the HEI is not implemented according to the good governance practice.

4) Regional HEI in Latvia should pay more attention to more comprehensive understanding of the internationalisation concept, covering various dimensions of it. The role of internationalisation of the higher education should be more clearly indicated in the strategic documentation of the HEI, indicating objectives and tasks towards implementation of it. In addition, the HEI should focus on development of inclusive environment that supports international students and staff as well as promotes the internationalisation of local students.

\section{Bibliography}

1. Altbach, P.G., Knight, J. (2007). The Internationalization of Higher Education: Motivations and Realities. Journal of Studies in International Education, Volume 11, p. 290.

2. Bernnell, P. (2020). The Internationalisation of Higher Education Provision in the United Kingdom: Patterns and Relationships between Onshore and Offshore Overseas Student Enrolment. International Journal of Educational Development, Volume 74, pp. 102-112.

3. British Council (2018). EI Feature - International Student Mobility to 2027: Local Investment, Global Outcomes. Report, British Council, UK, January. Retrieved: https://ei.britishcouncil.org/educationin telligence/ei-feature-international-student-mobility-2027-local-investment-global-outcome.

Access: 05.03.2020.

4. Chankseliani, M., Wells, A. (2019). Big Business in a Small State: Rationales of Higher Education Internationalisation in Latvia. European Educational Research Journal, Volume 18, Issue 6, pp. 639-655.

5. Clarke, M., Hui Yang, L., Harmon, D. (2018). The Internationalisation of Irish Higher Education Retrieved: http://eurireland.ie/assets/uploads/2018/07/report_internationalisation_of_education_2018.pdf. Access: 04.02.2020.

6. Ennew, C., Greenaway, D. (2012). The Globalisation of Higher Education. Houndmills, Basingstoke, U.K.

7. European Commission (2011). Supporting Growth and Jobs - An Agenda for the Modernisation of Europe's Higher Education Systems. COM $567 . \quad$ Retrieved: https://ec.europa.eu/assets/eac/education/library/policy/modernisation_en.pdf Access: 05.03.2020.

8. European Parliament (2015). Internationalisation of Higher Education - Study. Retrieved: http://www.europarl.europa.eu/RegData/etudes/STUD/2015/540370/IPOL_STU\%282015\%29540370_EN.p df.Access: 04.02.2020. 
9. Guidelines on the Development of Education 2014-2020. Latvijas Vestnesis, No. 103. Retrieved: https://m.likumi.lv/doc.php?id=266406. Access: 05.03.2020.

10. Kapur, D., Crowley, M. (2008). Beyond the ABCs: Higher Education and Developing Countries. Centre for Global Development, Washington D.C.

11. Knight, J. (2008). Higher Education in Turmoil. The Changing World of Internationalisation. Rotterdam, the Netherlands: Sense Publishers.

12. Ministry of Education and Science (2014). Guidelines for the Development of Education for 2014-2020. Retrieved: https://rio.jrc.ec.europa.eu/en/library/guidelines-development-education-2014-2020 Access: 04.02.2020.

13. Ministry of Education and Science (2019). Parskats par augstako izglitibu 2018 (Report on Higher Education). Retrieved:

https://www.izm.gov.Iv/images/statistika/augst_izgl/Augstakas_izglitibas_LV_parskats_2018.pdf. Access: 04.02.2020.

14. Ministry of Education and Science (2020). Konceptualais zinojums "Par augstskolu ieksejas parvaldibas mainu" - projekts (Draft Conceptual Report on Changing Internal Governance in Higher Education Institutions). Retrieved: https://izm.gov.Iv/images/sabiedribas_lidzdaliba/KZ_augstskolu_parvaldiba_24012020.pdf. Access: 04.02.2020.

15. OECD (2010). Higher Education in Regional and City Development: The Autonomous Region of Andalusia, Spain. OECD Publishing, $284 \mathrm{p}$.

16. OECD (2012). Higher Education in Regional and City Development: Wroclaw, Poland OECD Publishing, 276 p.

17. Pinheiro, R., Young, M., Sima, K. (2018). Higher Education and Regional Development: Tales from Northern and Cenral Europe. Springer International Publishing, 258 p.

18. Smaliakou, D.A. (2019). The Genesis of Higher Education Internationalisation. Education and Science, Volume 21, Issue 8, pp. 9-28.

19. The Council of the European Union (2011). Council Conclusions on a Benchmark for Learning Mobility. (2011/C 372/08).

Retrieved:

https://eurlex.europa.eu/LexUriServ/LexUriServ.do?uri=OJ:C:2011:372:0031:0035:EN:PDF. Access: 05.03.2020. 